Journal Universitas Muhammadiyah Gresik Engineering, Social Science, and Health International Conference (UMGESHIC)

UMGCINMATIC : $1^{\text {st }}$ Rethinking Education during Covid-19 Era: Challange and Innovation

\title{
THE EFFECT OF EXISTANCE, RELATEDNESS, GROWTH MOTIVATION AND PEER SOCIAL SUPPORT ON ADVERSITY QUOTIENT IN WORKING INDUSTRIAL ENGINEERING STUDENTS
}

\author{
Author \\ Maudy Annastasia ${ }^{1}$, Idha Rahayuningsih ${ }^{2}$ \\ Psychology Faculty, Universitas Muhammadiyah Gresik \\ Email: Maudya_170701@umg.ac.id ${ }^{1}$, idha.rahayuningsih@umg.ac.id ${ }^{2}$
}

\begin{abstract}
.
The problems experienced by students who study and work will certainly have an impact on achievement in lectures and work. Therefore, students need an adversity quotient to overcome this problem. One of the internal factors that influence the adversity quotient is motivation (existence, relatedness, growth). While the external factor that affects the adversity quotient is peer social support. This study aims to determine the effect of the level of motivation for existence, relatedness, growth, and the level of peer social support on the level of adversity quotient of working industrial engineering students. This research is a correlational study with a quantitative approach. Participants of 50 students were obtained by incidental sampling technique. The scale used in this study is a Likert scale with 4 answer choices. The validity test used is content validity while the reliability test uses Cronbach's alpha analysis. The data analysis technique used is nonlinear regression analysis. The results of this study indicate that the significance value of the motivational variable for growth in the relationship between existence is $0.495>0.05$ then Ho is accepted and Ha is rejected and the significance value of the peer social support variable is $0.003>0.05$ then $\mathrm{Ha}$ is accepted, Ho is rejected. The variable of growth motivation related to the existence and social support of peers contributed $44.5 \%$ to the adversity quotient variable. While the remaining $55.5 \%$ is influenced by other variables not examined. The benefit of this research is to add information on the development of psychology regarding the variables of adversity quotient, Motivation (existence, relatedness, growth), and peer social support. Limitations in this study are the minimum subject so that for further researchers are expected to add research subjects and can add independent variables.
\end{abstract}

Keywords: Motivation (existence, relatedness, growth), Social Support, and Adversity Quotient 


\section{INTRODUCTION}

Education has an important role in building this nation into a developed and educated nation. Not only that, but education is also an effort that a person can do to bring about change himself. Education gives a person the opportunity to seek knowledge. In addition, to seeking knowledge, education also has a role inside a person, namely to create morals and also as a means of extracting the potential that exists in a person. Of course, in this case, higher education can be done as an effort to achieve these goals. As stated in Article 19 of the National Education System Law, that higher education is education taken after secondary education which consists of several educational programs such as diplomas, bachelors, masters, specialists, and doctors organized by universities. Higher education itself has several forms such as academies, polytechnics, high schools, institutes, or universities (Apuanor, 2017:13).

In Indonesia, education is something that must be obtained by all citizens. Indonesia holds an education program, where the program is known as the 9-year compulsory education. This program contains the obligation of every Indonesian citizen to take education from elementary school to junior high school level. Education in Indonesia is currently good enough, it can be seen from the children today who not only want to go to junior high school but also want to study up to university students and become a graduate. That's because, in this day, the competition to enter the world of work is very difficult and tight. If you study up to university students and even undergraduates, it will open up opportunities to get a decent job (Lumbantobing, 2016:1).

The phenomenon of students who also work is not a new thing in Indonesia. Studying while working is not only done by students who lack in economic terms. Work is a manifestation of self-actualization, where according to Maslow self-actualization is the culmination of human needs. Self-actualization will be seen from the results of efforts that have been carried out optimally and seriously (Dudija, 2011:196). Data from the National Center for Education Statistics (NCES) states that in $200740 \%$ of students worked more than 20 hours per week (Orpina, 2019:120). There are various reasons behind students studying while working, ranging from economic problems, the desire to help parents in paying for college, seeking experience, wanting to fill spare time, get more pocket money for college needs, and gain knowledge. Nowadays, many students who are economically capable do not only study but also work because they want to get more pocket money and experience (Dudija, 2011:196).

Although it has many benefits, studying while working also has many risks, including difficulty in managing time, fatigue which causes laziness to come to campus, and not completing lectures and working on time. These various problems ultimately require students who work to be able to use time effectively to balance between studying 
and working (Lumbantobing, 2016:2). Even though working students have dual priorities, they still have to carry out their obligations, namely maintaining stable academic achievements, completing the education that has been chosen, and getting benefits from the education they are undergoing. So the student must be smart in dividing his time and concentration and be responsible for the dual role (Orpina, 2019:122). Dividing time between college and work usually depends on the ability of each individual to set himself to the target. If students cannot schedule these dual roles properly, the focus will be divided so that it can lead to conflicts between lectures and work matters, this is referred to as workstudy conflict (Octavia, 2013:46).

The challenges and risks of going to college and working can cause problems or difficulties that are not easy to deal with. Therefore, students need more adversity quotient to deal with this. Adversity Quotient helps students who work in dealing with problems and difficulties while undergoing lectures and work. Students who work need to improve and develop their adversity quotient in order to understand the source of problems both in lectures and at work, and be able to handle these problems quickly, accurately, and responsibly (Arifin, 2020:31). Someone with a high adversity quotient never makes obstacles a barrier to success. In addition, someone with a high adversity quotient is able to survive in the face of challenges and take advantage of these challenges as a means to multiply the potential that exists in him. A person with a high adversity quotient is also easy to recover when in a downturn or in difficult situations for him and continues to advance in the face of challenges that arise in the future. Meanwhile, someone who has a low adversity quotient tends to under-utilize their potential to deal with and resolve existing problems and difficulties.

This phenomenon of working students can also be found at the University of Muhammadiyah Gresik. This can be seen from the lecture activities which are divided into two classes, namely morning class, and afternoon class. Morning classes are usually filled by students who only focus on studying. While in the afternoon class, on average, it is chosen and filled by working students. Therefore, the researcher decided to conduct an interview. Researchers conducted interviews to find out the reasons students work. Based on the data or interview results, it can be concluded that the reasons students work are to fill spare time, to make their own money, so as not to be unemployed, to fulfill obligations, work demands, support performance, improve living standards, and seek knowledge. Based on the data or the results of the interviews above, it can be concluded that there are problems experienced by working students. These problems are in the form of difficulty dividing time between study and work, difficulty prioritizing between lectures and work matters, and feeling lazy to take courses because of fatigue at work. Because of these problems or conditions, it shows that the adversity quotient for working students is still low. Stoltz (2000:48) states that the negative impact felt by someone who has a low adversity quotient 
is not being able to survive when faced with difficulties. The difficulty of prioritizing between lectures and work matters, and feeling lazy to take courses because of fatigue at work. Because of these problems or conditions, it shows that the adversity quotient for working students is still low. Stoltz (2000:48) states that the negative impact felt by someone who has a low adversity quotient is not being able to survive when faced with difficulties. The difficulty of prioritizing between lectures and work matters, and feeling lazy to take courses because of fatigue at work. Because of these problems or conditions, it shows that the adversity quotient for working students is still low. Stoltz (2000:48) states that the negative impact felt by someone who has a low adversity quotient is not being able to survive when faced with difficulties.

Stoltz (2000:8) states that the adversity quotient is a person's ability to face and overcome difficulties. The adversity quotient is high enough to make a person tend to survive until successful. Meanwhile, someone with a low adversity quotient will not be able to survive when faced with difficulties so that the person suffers in all areas of his life.

Stoltz (2000:92) states that a person's adversity quotient is influenced by several factors such as (1) competitiveness, related to hope and tenacity which is determined by the way a person faces difficulties (2) productivity, a person can be said to be productive if he can respond to difficulties positively (3) creativity, demands a person's ability to overcome difficulties caused by unexpected things (4) motivation, motivated people can have a high enough adversity quotient (5) take risks, people who can control difficulties take more risks (6) improvement, people with a high enough adversity quotient will always want to be even more than before (7) persistence, if a person responds to adversity well, he will recover more quickly from adversity (8) learn, with an optimistic attitude one can learn a lot from the difficulties faced (9) embrace change, someone who can adapt to change tends to respond to difficulties constructively (10) tenacity, makes a person able to rise again when faced with difficulties. The adversity quotient itself has several dimensions. According to Stoltz (2000:141-166), there are four dimensions of fighting power, including Adversity quotient itself has several dimensions power, including Control, Origin \& Ownership, Reach, and Endurance. Based on the results of the interviews that have been conducted, it can be concluded that the factors that can increase the adversity quotient include motivation, calm, positive thinking, clear goals, time management, discipline, gratitude, social support, responsibility, and priority on things that are important to you. important. The dominant factors from the results of the interview are factors of motivation and social support.

Motivation is defined as a process related to a person's strength, direction, and persistence in his efforts to achieve certain goals (Robbins \& Judge, 2013:127). In motivation, there are several theories put forward by several experts, one of which is Alderfer's theory. Alderfer suggests that there are three hierarchies in core needs, namely 
the need for existence (Existence), the need for relatedness (Relatedness), and the need for growth (Growth) (Mayvita, Astuti, \& Ruhana, 2017:170). Research conducted by Putra (2016) with the title "The Relationship between Achievement Motivation and Adversity Quotient of Adolescent Inmates At LPKA Class II Sukamiskin Bandung" the results are Spearmen-rank correlation analysis shows that there is a relationship between achievement motivation and adversity quotient with a value of $r=0.724$ and $p$-value $=0,00$. The analysis shows that in this study there is a relationship between achievement motivation and the adversity quotient which is positive with a strong and significant level of attachment.

Social support is a sense of comfort, a sense of caring, and the ministration provided to someone, both from other people and from other groups (Sarafino, 2011:81). Peer social support is a ministration or support provided by peers that can be felt by individuals when needed so that individuals feel loved and appreciated by the surrounding environment (Sari \& Indrawati, 2016:178). Sarafino (2011:81) states that there are four aspects of social support, these aspects include emotional support. Research conducted by Puspasari (2012) with the title "Social Support and Adversity Quotient in Adolescents who Experiencing School Transition" result is that data analysis shows $r=0.520, p=0.000(p<0,01)$ which means that there is a very significant positive relationship between social support and the adversity quotient. From the results of these studies, it can be concluded that social support has an effect on the adversity quotient during the adolescent school transition period.

\section{METHODS}

The type of research used in this research was the type of quantitative research. The type of research in this research was correlational research. According to Winarno (2013:57), correlational research is intended to reveal the relationship between variables. The population in this study were students of the University of Muhammadiyah Gresik, the 2018 Industrial Engineering Study Program. The sampling technique used in this study was a non-probability sampling technique. One of the non-probability sampling techniques chosen for this research was census or total sampling. Census or total sampling is a sampling technique in which all members of the population are sampled. Research conducted on populations under 100 should use a census or total sampling (Sugiyono, 2019:134). The sample of this research was the Industrial Engineering Study Program students who are studying and working, totaling 52 students. The data collection technique in this study was a questionnaire using a Likert scale. This study used a Likert scale by using four alternative answer choices, namely, the answer is very appropriate (SS), appropriate (S), not suitable (TS), very inappropriate (STS). In this study, researchers used content validity. An instrument is said to be content validity of the instrument is in 
accordance with the content.

This study used a Likert scale by using four alternative answer choices, namely, the answer is very appropriate (SS), appropriate (S), not suitable (TS), very inappropriate (STS). In this study, researchers used content validity. An instrument is said to be content validity of the instrument is in accordance with the content. This study used a Likert scale by using four alternative answer choices, namely, the answer is very appropriate (SS), appropriate (S), not suitable (TS), very inappropriate (STS). In this study, researchers used content validity. An instrument is said to be content validity of the instrument is in accordance with the content. Item selection criteria were based on item-total correlation using $r_{i x} \geq 0.30$ limit. All items that achieve a correlation coefficient of at least 0.30 differentiating power are considered satisfactory. Items that have a price of $r_{i x} \geq 0.30$ can be interpreted as items that have low discriminating power. If the number of items that pass does not meet the desired number, it can be considered to reduce the criteria limit a little, for example to 0.25 so that the desired number of items is achieved (Azwar, 2017:86). There are several types of reliability tests used in this study, but the one that will be used in this study is the alpha-Cronbach reliability test. The Cronbach Alpha test has provisions based on the magnitude of the reliability coefficient ranging from 0.00 to 1.00 . In this study, the data that has been collected will be analyzed using regression analysis techniques. The regression analysis technique used in this research is non-linear regression analysis with a quadratic model. Then the statistical analysis used the IBM SPSS for windows version 25.0 program.

\section{DISCUSSION}

After testing the validity and reliability of the adversity quotient questionnaire, the motivation for existence relatedness growth, and peer social support, the invalid items were not used and the valid items were used in data analysis in this study. The results of the normality test showed that there is one variable that is normally distributed, while the other two variables are not normally distributed. So to determine the effect between variables, a non-parametric statistical approach was used using a non-linear regression operating system.

Table 1.1 Non-Linear Regression Test Results With Quadratic Model on ERG Motivation Variables on Adversity Quotient

\begin{tabular}{r|r|r|r} 
& & \multicolumn{2}{|c}{$\begin{array}{r}\text { Model Summary } \\
\text { Adjusted R } \\
\text { Square }\end{array}$} \\
\hline .501 & R Square & .219 & $\begin{array}{c}\text { Std. Error of the } \\
\text { Estimate }\end{array}$ \\
\hline
\end{tabular}

The independent variable is ERG motivation. 
Source: SPSS version 25 for windows

Based on table 1.1 the results of the regression analysis showed that the $\mathrm{R}$ square value is 0.251 or $25.1 \%$. While others are influenced by other factors that are not examined by researchers.

Table 1.2 Test results in Non-Linear Regression Coefficient With Quadratic Model on ERG Motivation Variables on Adversity Quotient

\begin{tabular}{|c|c|c|c|c|c|}
\hline \multicolumn{6}{|c|}{ Coefficients } \\
\hline & \multirow{2}{*}{\multicolumn{2}{|c|}{ Unstandardized Coefficients }} & \multirow{3}{*}{$\begin{array}{c}\text { Standardized } \\
\text { Coefficients } \\
\text { Beta }\end{array}$} & \multirow[b]{3}{*}{$\mathrm{t}$} & \multirow[b]{3}{*}{ Sig. } \\
\hline & & & & & \\
\hline & $\mathrm{B}$ & Std. Error & & & \\
\hline ERG motivation & -1.888 & 2,747 & -1.376 & -.687 & .495 \\
\hline ERG Motivation $* * 2$ & .022 & .023 & 1,867 & .933 & .356 \\
\hline (Constant) & 99,672 & 80,331 & & 1,241 & .221 \\
\hline
\end{tabular}

Source: SPSS version 25 for windows

Based on table 1.2 the test results obtained a significance value of $0.495>0.05$ then Ho accepted Ha rejected. So it can be concluded that there is no influence of existencerelatedness growth motivation on adversity quotient. This means that even though it has a high level of existence relatedness growth motivation, it does not affect the level of adversity quotient.

Table 1.3 Non-Linear Regression Test Results With Quadratic Model on Peer Social Support Variables on Adversity Quotient

\begin{tabular}{r|r|r|r} 
& & \multicolumn{2}{c}{ Model Summary } \\
$\mathrm{R}$ & $\mathrm{R}$ Square & Adjusted R Square & $\begin{array}{c}\text { Std. Error of the } \\
\text { Estimate }\end{array}$ \\
\hline .440 & .194 & .160 & 7.345 \\
\hline
\end{tabular}

The independent variable is TS Social Support.

Based on table 1.3 the results of the regression analysis showed that the value of $R$ square is 0.194 or $19.4 \%$. While some other values are influenced by other factors are not examined by researchers.

Table 1.4 Test results in Non-Linear Regression Coefficient With Quadratic Model On Peer Social Support Variable Against Adversity Quotient

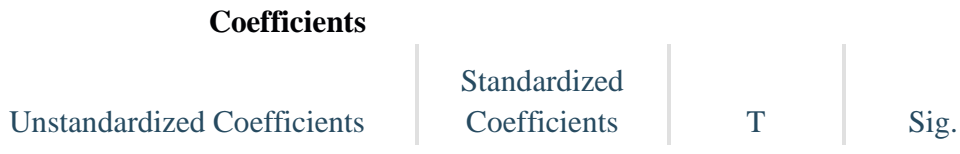


UMGCINMATIC: $1^{\text {st }}$ Rethinking Education during Covid-19 Era: Challange and Innovation Volume 1 No 2

\begin{tabular}{|c|c|c|c|c|c|}
\hline & B & Std. Error & Beta & & \\
\hline TS Social Support & 6.362 & 2,049 & 5.420 & 3.106 & .003 \\
\hline TS Social Support $* * 2$ & -.047 & .016 & $-5,235$ & $-3,000$ & .004 \\
\hline (Constant) & -146.360 & 65.838 & & -2.223 & .031 \\
\hline
\end{tabular}

Source: SPSS version 25 for windows

Based on table 1.4, the results obtained the result of the significant value of $0.003<$ 0.05 then $\mathrm{Ho}$ is rejected and $\mathrm{Ha}$ is accepted. So it can be concluded that there is an influence of peer social support on the adversity quotient. This means that the higher the level of peer social support, the higher the adversity quotient.

The first hypothesis shows that there is no influence between the level of motivation of existence-relatedness growth and the level of adversity quotient with a significance value of $0.495>0.05$. So the first hypothesis is rejected. The second hypothesis shows that there is an influence between the level of peer social support on the level of adversity quotient with a significance value of $0.003<0.05$. So that the second hypothesis is accepted. Based on the results of this study, which states that there is a positive influence between social support and the adversity quotient, it is in line with the research conducted by Nurwahidah (2018) which stated that the results of data processing obtained a sig value. P-value $=0.358$ ( $\mathrm{p}$-value > 0.05), which means that there is no influence of social support, there is an adversity quotient for injecting drug users who take part in the Methadone Maintenance Therapy Program.

According to Saidah \& Aulia (2014), there are several factors that influence the adversity quotient including talent, willingness (motivation), intelligence, health, personality characteristics, genetics, education, and self-confidence (self-efficacy). Meanwhile, according to Efnita et al (2007), the factors that influence the adversity quotient include religiosity factors, internal motivation, self-confidence and abilities, modeling factors from parents, environmental factors that lead a person to survive in difficult circumstances, and self-actualization factor.

\section{CONCLUSION}

Based on the results and discussion in this study, it can be concluded that the value of R Square showed the results of $25.1 \%$ from the existence relatedness growth motivation variable and $19.4 \%$ from the peer social support variable. So that, the variable of existence relatedness growth motivation and peer social support variable contributed $44.5 \%$ to the adversity quotient variable. While the remaining $55.5 \%$ is influenced by other variables that are not examined. This means that the motivation for existence relatedness growth cannot increase the adversity quotient. Meanwhile, peer social support has a contribution in increasing the adversity quotient. It can be said that students who have high peer social 
support can affect the level of adversity quotient in these students.

\section{REFERENCES}

Apuanor, Sudarmono and M. Arifin, "Motivasi Menyelesaikan Skripsi Mahasiswa yang Bekerja Dan Tidak Bekerja," Jurnal Paedagogie Volume V Nomor 1, pp. 13-20, 2017.

P. A. Lumbantobing, "Hubungan Adversity Quotient Dan Dukungan Sosial Dengan Prokrastinasi Akademik Dalam Penyelesaian Skripsi Pada Mahasiswa yang Bekerja Di PTS STMIK-STIE Mikroskil Medan," Jurnal Mutiara Pendidikan Indonesia, 10/08, pp. 1-14, 2016.

N. Dudija, "Perbedaan Motivasi Menyelesaikan Skripsi Antara Mahasisya yang Bekerja Dengan Mahasiswa yang Tidak Bekerja," Humanitas Vol. VIII No.2, pp. 196-206, 2011.

S. Orpina and S. A. Prahara, "Self-efficacy dan Burnout Akademik pada Mahasiswa yang Bekerja," Indonesian Journal of Educational Counseling, pp. 119-130, 2019.

E. Octavia and S. P. Nugraha, "HUBUNGAN ANTARA ADVERSITY QUOTIENT DAN WORK-STUDY CONFLICTPADA MAHASISWA YANG BEKERJA," Jurnal Psikologi Integratif Vol. 1 No. 1, pp. 44-51, 2013.

N. Arifin, "Efektivitas Pembelajaran Sistem Problem Based Learning Ditinjau Dari Daya Juang Dan Kemampuan Pemecahan Masalah Matematis Mahasiswa PGSD," Jurnal Pendidikan Matematika Indonesia Volum 5 Nomor 1, pp. 31-38, 2020.

P. G. Stoltz, Adversity Quotient Mengubah Hambatan Menjadi Peluang, Jakarta: PT Gramedia Widiasarana Indonesia, 2000.

P. S. Robbins and A. T. Judge, Organizational Behavior, United States of America: Pearson Education, Inc, 2013.

S. A. Mayvita, E. S. Astuti and I. Ruhana, "Pengaruh Motivasi Existance, Relatedness, Growth (ERG) Terhadap Prestasi Kerja," Jurnal Administrasi Bisnis (JAB) Vol. 47 No. 2, pp. 168-176, 2017.

E. P. Sarafino and T. W. Smith, Health Psychology, United States of America: John Wiley \& Sons, INC, 2011.

P. K. P. Sari and E. S. Indrawati, "Hubungan Antara Dukungan Sosial Teman Sebaya Dengan Resiliensi Akademik Pada Mahasiswa Tingkat Akhir Jurusan X Fakultas Teknik 
Universitas Diponegoro," Jurnal Empati Vol. 5 No. 2, pp. 177-182, 2016.

D. A. Puspasari, T. Kuwato and H. E. Wijaya, "Dukungan Sosial Dan Adversity Quotient Pada Remaja yang Mengalami Transisi Sekolah," Psikologika Vol. 17 No. 1, pp. 69-75, 2012.

M. E. Winarno, Metodologi Penelitian Dalam Pendidikan Jasmani, Malang: Universitas Negeri Malang (UM Press), 2013.

Sugiyono, Metode Penelitian Kuantitatif, Kualitatif, dan R\&D, Bandung: Alfabeta, 2019.

S. Azwar, Reliabilitas Dan Validitas (Cetakan IV), Yogyakarta: Pustaka Pelajar, 2017. 